\title{
QUALITY ASSESSMENT OF DELIVERY IN THE SUPPLY CHAIN OPTIMIZATION
}

Marcin Gaura $^{\mathrm{a}}$, Maciej Kubońb,c, Zbigniew Kowalczyk ${ }^{\mathrm{b}}$, Dariusz Kwaśniewski ${ }^{\mathrm{b}}$, Zbigniew Daniel $^{\mathrm{b}}$, Krzysztof Kapela ${ }^{\mathrm{d}}$

a Student of Department of Production Engineering, Logistics and Applied Informatics, University of Agriculture in Krakow, e-mail: marcingaura@interia.pl

b Department of Production Engineering, Logistics and Applied Informatics, University of Agriculture in Krakow, e-mail: maciej.kubon@urk.edu.pl, ORCID 0000-0003-4847-8743; e-mail: zbigniew.kowalczyk@urk.edu.pl, ORCID 0000-0001-8001-2092; e-mail: dariusz.kwasniewski@urk.edu.pl, ORCID 0000-0002-1873-1456; e-mail: zbigniew.daniel@urk.edu.pl, ORCID 0000-0001-5507-8911

c Institute of Technical Sciences, Eastern European State University in Przemyśl, Książąt

Lubomirskich 6, 37-700 Przemyśl; maciej.kubon@urk.edu.pl, ORCID 0000-0003-4847-8743

${ }^{d}$ Faculty of Agrobioengineering and Animal Husbandry, University of Natural Sciences and Humanities in Siedlce, e-mail: krzysztof.kapela@uph.edu.pl, ORCID 0000-0002-3415-7781

*Corresponding author: e-mail: maciej.kubon@urk.edu.pl

\begin{tabular}{l}
\hline ARTICLE INFO \\
\hline Article history: \\
Received: August 2020 \\
Received in the revised form: \\
September 2020 \\
Accepted: September 2020 \\
\hline Keywords: \\
logistics, \\
quality, \\
delivery, \\
assessment, \\
supply \\
\hline
\end{tabular}

ABSTRACT

The paper discusses supplier evaluation as a tool for controlling the level of service in a production enterprise based on data from the selected production company. The suppliers were assessed and analyzed based on their respective assortment groups and strengths and weaknesses of their activity were indicated. It was found that the supply chain in the analyzed company is largely determined by the type of ordered goods, the place of its production and the method of its distribution to the customer.

\section{Introduction}

One of the key challenges modern logistics faces is the issues related to the management and functioning of the contemporary supply chain (Coyle, Bardi, Langley, 2012). The latest trends and concepts of supply chain management (SCM) relate to creating the possibilities of comprehensive management of all its links and processes. Effective management of the contemporary supply chain requires not only discerning all the processes and links of this chain, but also automating many processes (Witkowski, 2010; Iakovou, 2014). Effective and flexible supply chain management also requires acquiring lots of data in real time. Meeting the expectations towards the contemporary and prospective supply chains, which are related to the permanent reduction of costs and implementation time of logistic activities is more and more difficult, more complicated and requires taking into account more and more data, often variable (Blaik, 2010; Bujak, 2015). One of the key tasks of logistics is the effective 
M. Gaura, M. Kuboń, Z. Kowalczyk, et.al.

management of the enterprise supply chain, including planning, creation, as well as continuous improvement and implementation of functional improvements. Nowicka-Skowron (2000) states that the supply chain includes activities both in a single enterprise and between enterprises, taking into account the flow of goods and services, as well as finances and information. The supply chain, its planning and supervision, constitute a key process of delivery logistics (Maloni, 2006; Kolasińska-Morawiecka, 2011).

To ensure the smooth procurement process in the enterprise, it is also necessary to create a strong network of suppliers and contractors responsible for delivering the most important assortment. Building a strong partnership based on strategic suppliers makes it easier to build a company's competitive advantage in a given market by improving the quality of the offered procurement services and lowering the prices of the supplied goods. It also allows analyzing, detecting and reducing unnecessary activities and obstacles towards smooth delivery of goods, information and cash, as well as cutting down the time of these flows (Krygier, 2011). In order to achieve customer satisfaction and provide the best quality products and the highest level of services, the company should create measurable quality goals that help control and constantly improve the services provided by its suppliers (Twaróg, 2005; Ficoń, 2008). The key areas of cooperation include: optimal performance of product quality, on-time delivery, cost and continuous improvement in individual areas. It is a set of actions aimed at resolving the detected problems and preventing them from re-emerging in the future (Kubon, 2007; Wajszczuk, 2016).

One of the basic tasks in delivery logistics is the selection and evaluation of suppliers. Supplier score and the quality of their services in the delivery of materials and components largely depend on the specific requirements of the customer. The most common criterion for selecting suppliers that were qualified for the evaluation is the scale of cooperation in business terms (e.g. annual turnover or the number of orders completed in a given period of time). Very often, a newly identified supplier with a high potential is also assessed in order to establish the most convenient terms of cooperation at its early stage. When broad cooperation and good relations with suppliers are established, it is easier to set up specific terms of delivery, to point the supplier to the customer's requirements and to grow the cooperation in its respective aspects. The main reason why a regular evaluation of the supplier's activities is carried out is to assure the organization and its clients that the contractors qualified for cooperation meet the requirements declared at contract negotiations (Owsiak, et al., 2013). After the stage of qualifying suppliers and establishing the detailed terms of cooperation between the parties, it is also necessary to verify compliance with individual aspects in the later stages of delivery. The supplier assessment thus enables the identification of weak points in the delivery process (Kuboń, 2007) and its optimization by taking corrective actions to eliminate them. Regularly collected data allows extracting valuable information and precisely indicating current trends for strategic delivery indexes of a given assortment (Pfohl, 2001).

\section{Purpose and scope of work}

The aim of the research was to assess the quality of delivery as exemplified by a selected company. The main criterion for selecting suppliers for the evaluation was the number of product lines delivered to the company. They were selected from five assortment groups with the largest number of product lines delivered to the selected company. The thus selected criterion for supplier assessment also limits the impact of exceptional situations, both incidental 
Quality assessment of delivery...

and individual, on the overall picture of suppliers' activities in the course of cooperation with a selected production company. The scope of work covered the deliveries of fifty suppliers from five assortment groups in 2018.

\section{Objective, scope, and method of work}

The aim of the research was to assess the quality of delivery as exemplified by a selected company. The main criterion for selecting suppliers for the evaluation was the number of product lines delivered to the company. They were selected from five assortment groups with the largest number of product lines delivered to the selected company. The thus selected criterion for supplier assessment also limits the impact of exceptional situations, both incidental and individual, on the overall picture of suppliers' activities in the course of cooperation with a selected production company. The scope of work covered the deliveries of fifty suppliers from five assortment groups in 2018.

The analyzed data was exported from the company's Business Intelligence tool, which collects ans saves data in the Oracle database. The supplier data were filtered and selected in such a way as to obtain information on deliveries from three individual product groups in accordance with the adopted selection criteria. Following a selection of the appropriate year, assortment group and the number of delivered order lines in the adopted period of time, a list of ten suppliers was selected for each assortment group, with the largest number of deliveries completed in the selected year. The collected information is presented in the form of tables.

The supplier assessment was based on the results of four selected Key Performance indexes (KPIs) which were adopted as the general benchmark for measuring the quality of services provided by contractors in the delivery of goods. The selected suppliers will be assessed for individual indexes, based on which their overall assessment will be made. The exported results of each assortment group of suppliers have been summarized in a tabular form. Then, the mean scores for individual groups for each of the measured indexes were taken from each collective assessment sheet in order to compare the relationships and assess the characteristics of individual groups. For the assessment, the following indexes were taken into account:

- average delivery time (days),

- timeliness of delivered product lines (\%),

- logistical inconsistencies in admitting goods into the warehouse (\%),

- quality of deliveries measured by the PPM level index.

For the purpose of the assessment, a dedicated scoring key was created for each of the indexes in order to provide a measurable presentation of the level of service of the company's largest suppliers. After the assessment, each of the suppliers was assigned one of the three statuses:

- Preferred - the highest possible status, which proves the high quality of the order delivery process in the enterprise.

- Accepted - supplier performance continues to be positive, but there is room for improvement to further improve the level of service provided. 
M. Gaura, M. Kuboń, Z. Kowalczyk, et.al.

- Provisionally accepted - the lowest possible status, proving that the supplier is not at the best level in particular areas and requires the introduction of appropriate corrective actions aimed at the fastest and effective improvement of the delivery process.

The overall scoring range is the score sum for each index. Table 1 shows the scoring range for supplier ratings.

Table 1.

Supplier scoring scope

\begin{tabular}{ll}
\hline Score threshold & Supplier status \\
\hline$>51$ & PREFERRED \\
$>31$ & ACCEPTED \\
$<31$ & PROVISIONALLY ACCEPTED \\
\hline
\end{tabular}

\section{Research results}

After collecting the material and compiling the results of the evaluation of selected suppliers, the results were summarized in the form of tables broken down into individual product groups. The tables contain detailed information on the evaluation of each supplier with a detailed listing by individual indexes. It also contains collective information for the entire assortment group. Data analysis was performed to determine the current quality level of delivery for the selected criteria. Based on the obtained data and the adopted scores, following an evaluation, the suppliers were awarded appropriate results and status marked with a color.

Green - PREFERRED supplier,

Blue - ACCEPTED supplier,

Red - PROVISIONALLY ACCEPTED supplier.

Tables 2-4 show the results of supplier assessment for the selected product groups:

1) Electromechanics - a group of suppliers that produces and supplies cables, harnesses, wires and connectors. Most often these are custom components made in accordance with the design and the required technical specification, but very often these are standard catalog parts sold by distribution networks.

2) Semiconductors - electronic components with specific parameters that play a functional role in the finished product: integrated circuits, resistors, capacitors, varistors, transistors, coils, chokes, etc. These components are very rarely manufactured to special order in accordance with the design and required technical specification. The most common are standard catalog components available from distribution networks.

3) PCB printed circuits - custom elements made to order in accordance with the design and the required technical specification. They are the basic component for electronic products.

Suppliers from the assortment group Electromechanics was assessed at 31 points which is an acceptable score, with some areas for improvement. Of the ten vendors assessed, only 
Quality assessment of delivery...

one achieved the Preferred status, i.e. Supplier no. 4, who achieved a score of 55 thus exceeding the acceptability threshold in all measured indexes. Five suppliers have achieved the intermediate Accepted status, while four suppliers were awarded the lowest status, Provisionally Accepted. The lowest score was awarded to Supplier no. 10, i.e. only 5 points. The total of delivered product lines in the analyzed year amounted to 13,086 . The number of orders in the studied year was relatively large due to the small size of the delivered products and the high minimum quantity of the orders, which is required by the producers. A single finished product often includes several components from a given assortment group. An average delivery time of 32 days is acceptable. The goods come directly from the producers. The production process requires creating no stocks, although most manufacturers still use their customer's forecasts and production schedules. The timeliness of deliveries is $87.5 \%$ and the index score is below the minimum acceptability threshold. Due to the high seasonal workload, the supplier often delayed the previously confirmed delivery dates due to lack of production capacity. The logistic discrepancies at the admission amounted to $3.3 \%$.

Table 2.

Summary of the supplier evaluation results for the Electromechanics group

\begin{tabular}{|c|c|c|c|c|c|c|c|c|c|c|c|}
\hline \multicolumn{3}{|c|}{$\begin{array}{l}\text { General information } \\
\text { about the suppler }\end{array}$} & & \multicolumn{2}{|c|}{$\begin{array}{c}\text { Average } \\
\text { delivery } \\
\text { time }\end{array}$} & \multicolumn{2}{|c|}{$\begin{array}{l}\text { Timeliness } \\
\text { of deliveries }\end{array}$} & \multicolumn{2}{|c|}{$\begin{array}{c}\text { Quality } \\
\text { of deliveries }\end{array}$} & \multicolumn{2}{|c|}{$\begin{array}{l}\text { Non-compli- } \\
\text { ance receipts }\end{array}$} \\
\hline$\stackrel{\vec{\Xi}}{\ddot{n}}$ & 苛 & 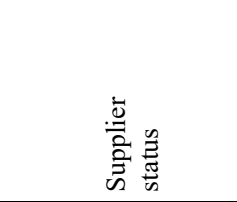 & 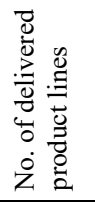 & 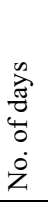 & 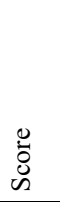 & $\overline{\stackrel{0}{0}}$ & 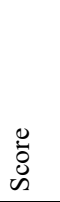 & 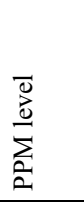 & 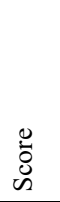 & $\bar{\Xi}$ & $\begin{array}{l}0 \\
\ddot{0} \\
\varkappa\end{array}$ \\
\hline Supplier 1 & 40 & ACCEPTED & 1839 & 11 & 15 & $77.8 \%$ & 0 & 6 & 20 & $4.1 \%$ & 5 \\
\hline Supplier 2 & 40 & ACCEPTED & 1598 & 8 & 15 & $98.6 \%$ & 15 & 1797 & 0 & $1.0 \%$ & 10 \\
\hline Supplier 3 & 40 & ACCEPTED & 1553 & 33 & 5 & $95.1 \%$ & 10 & 17 & 20 & $5.9 \%$ & 5 \\
\hline Supplier 4 & 55 & PREFERRED & 1548 & 11 & 15 & $99.0 \%$ & 15 & 36 & 20 & $2.8 \%$ & 5 \\
\hline Supplier 5 & 17 & $\begin{array}{l}\text { PROVISIONALLY } \\
\text { ACCEPTED }\end{array}$ & 1308 & 90 & 0 & $93.1 \%$ & 5 & 793 & 2 & $0.9 \%$ & 10 \\
\hline Supplier 6 & 50 & ACCEPTED & 1293 & 18 & 10 & $97.4 \%$ & 15 & 1 & 20 & $2.1 \%$ & 5 \\
\hline Supplier 7 & 10 & $\begin{array}{l}\text { PROVISIONALLY } \\
\text { ACCEPTED }\end{array}$ & 1137 & 42 & 5 & $89.4 \%$ & 0 & 4142 & 0 & $4.8 \%$ & 5 \\
\hline Supplier 8 & 15 & $\begin{array}{l}\text { PROVISIONALLY } \\
\text { ACCEPTED }\end{array}$ & 1008 & 23 & 10 & $86.1 \%$ & 0 & 1245 & 0 & $3.0 \%$ & 5 \\
\hline Supplier 9 & 35 & ACCEPTED & 950 & 24 & 10 & $60.3 \%$ & 0 & 0 & 20 & $3.8 \%$ & 5 \\
\hline Supplier 10 & 5 & ACCEPTED & 852 & 61 & 0 & $78.1 \%$ & 0 & 4511 & 0 & $4.3 \%$ & 5 \\
\hline Mean & 31 & & 13086 & 32 & & $87.5 \%$ & & 1255 & & $3.3 \%$ & \\
\hline
\end{tabular}


M. Gaura, M. Kuboń, Z. Kowalczyk, et.al.

The level of the index is at an acceptable level. The number of incidents was small, especially considering the relatively large number of delivered product lines. Average quality of delivery score (PPM) was 1225. The quality of the delivered products exceeds the acceptance threshold. However, on an annual basis it can be considered Acceptable. It is easier for the producer to take care of their own product quality and to introduce improvements and corrective actions.

Table 3.

Summary of the supplier evaluation results for the Semiconductors group

\begin{tabular}{lcccc}
\hline $\begin{array}{l}\text { General information } \\
\text { about the suppler }\end{array}$ & $\begin{array}{c}\text { Average de- } \\
\text { livery time }\end{array}$ & $\begin{array}{c}\text { Timeliness } \\
\text { of deliveries }\end{array}$ & $\begin{array}{c}\text { Quality } \\
\text { of deliveries }\end{array}$ & $\begin{array}{c}\text { Non-com- } \\
\text { pliance re- } \\
\text { ceipts }\end{array}$
\end{tabular}

\begin{tabular}{|c|c|c|c|c|c|c|c|c|c|c|c|}
\hline 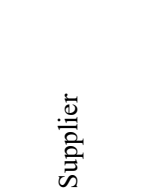 & 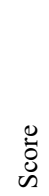 & 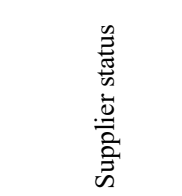 & 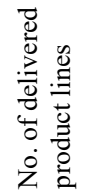 & 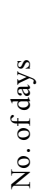 & $\begin{array}{l}0 \\
\check{\delta} \\
\mathscr{\leftrightarrow}\end{array}$ & ब. & $\begin{array}{l}0 \\
\check{\delta} \\
\mathscr{\leftrightarrow}\end{array}$ & $\frac{\bar{d}}{\sum_{0}^{0}}$ & $\begin{array}{l}0 \\
\check{\delta} \\
\ddot{n}\end{array}$ & ब्ల & 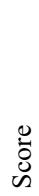 \\
\hline Supplier 1 & 55 & PREFERRED & 7351 & 11 & 15 & $98.7 \%$ & 15 & 2 & 20 & $2.5 \%$ & 5 \\
\hline Supplier 2 & 60 & PREFERRED & 5793 & 10 & 15 & $97.2 \%$ & 15 & 0 & 20 & $0.8 \%$ & 10 \\
\hline Supplier 3 & 60 & PREFERRED & 5524 & 10 & 15 & $99.0 \%$ & 15 & 121 & 20 & $1.7 \%$ & 10 \\
\hline Supplier 4 & 60 & PREFERRED & 3249 & 12 & 15 & $96.9 \%$ & 15 & 0 & 20 & $2.0 \%$ & 10 \\
\hline Supplier 5 & 40 & ACCEPTED & 1508 & 19 & 10 & $91.3 \%$ & 5 & 0 & 20 & $4.2 \%$ & 5 \\
\hline Supplier 6 & 60 & PREFERRED & 1100 & 13 & 15 & $99.5 \%$ & 15 & 12 & 20 & $1.8 \%$ & 10 \\
\hline Supplier 7 & 50 & ACCEPTED & 891 & 10 & 15 & $95.2 \%$ & 10 & 1 & 20 & $4.5 \%$ & 5 \\
\hline Supplier 8 & 60 & PREFERRED & 815 & 8 & 15 & $97.3 \%$ & 15 & 0 & 20 & $1.1 \%$ & 10 \\
\hline Supplier 9 & 30 & $\begin{array}{l}\text { PROVISION- } \\
\text { ALLY } \\
\text { ACCEPTED }\end{array}$ & 805 & 16 & 10 & $89.1 \%$ & 0 & 4 & 20 & $6.6 \%$ & 0 \\
\hline Supplier 10 & 55 & PREFERRED & 705 & 10 & 15 & $98.0 \%$ & 15 & 0 & 20 & $2.5 \%$ & 5 \\
\hline Mean & 53 & & 27741 & 12 & & $96.2 \%$ & & 14 & & $2.8 \%$ & \\
\hline
\end{tabular}

In the Semiconductors supplier group the average evaluation score was 53 points, which is a very high score in relation to the other assortment groups. Out of the ten assessed suppliers, as many as seven obtained the Preferred status. Two vendors obtained the Accepted status and one Supplier, no. 9, scored under 31 points and was awarded the Temporary Accepted status. The total of the delivered product lines was 27,741. A very large number of delivered product lines results from the huge demand for parts for the production of electronic components. Additionally, a single PCB circuit can even include several hundred semiconductor components. The average delivery time was 12 days. The very short average delivery time is due to the fact that the assortment comes from the distribution network and not directly from the parts manufacturers. Therefore, in this case, the production time is not taken into account. Forecasts are only used for components with limited market availability. Timeliness of deliveries was at $96.2 \%$. The high timeliness of deliveries results mainly from the large stocks 
Quality assessment of delivery...

of distributors. Hence, there is no major problem with organizing the shipment of the order within a few working days. The logistic discrepancies in the admission were at $2.8 \%$. Logistic incidents were at an acceptable level; it is difficult to avoid minor mistakes, especially with such a high number of delivered product lines. Good and quick contact with representatives allows reacting quickly and solving problems. Average quality of delivery score (PPM) was 14. The quality of delivered products in terms of PPM is very high. The large number of delivered product lines affects the overall PPM level. In case of a complaint, the index level is not high. Quality problems are sporadic, most often functional in nature.

Table 4

Summary of the supplier evaluation results for the PCB printed circuits group

\begin{tabular}{|c|c|c|c|c|c|c|c|c|c|c|c|}
\hline $\begin{array}{l}\text { General info } \\
\text { about the sur }\end{array}$ & $\begin{array}{l}\text { mati } \\
\text { pler }\end{array}$ & & & $\begin{array}{r}\text { Av } \\
\text { deliv }\end{array}$ & & $\begin{array}{l}\text { Timelir } \\
\text { of deliv }\end{array}$ & $\begin{array}{l}\text { ess } \\
\text { ries } \\
\end{array}$ & $\begin{array}{r}\text { Qua } \\
\text { of deli } \\
\end{array}$ & $\begin{array}{l}\mathrm{y} \\
\text { ries }\end{array}$ & $\begin{array}{r}\text { Non-cor } \\
\text { rece }\end{array}$ & ance \\
\hline 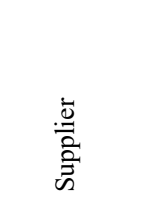 & 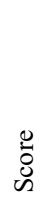 & 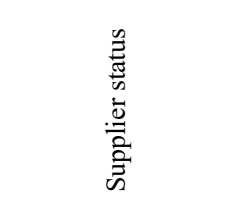 & 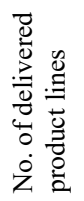 & 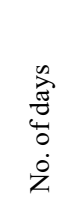 & 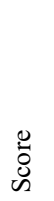 & 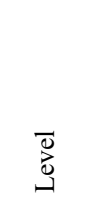 & 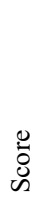 & 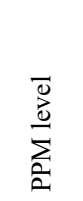 & 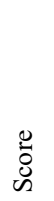 & 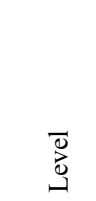 & 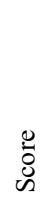 \\
\hline Supplier 1 & 10 & $\begin{array}{l}\text { PROVISIONALLY } \\
\text { ACCEPTED }\end{array}$ & 801 & 45 & 10 & $73.3 \%$ & 0 & 1993 & 0 & $6.3 \%$ & 0 \\
\hline Supplier 2 & 5 & $\begin{array}{l}\text { PROVISIONALLY } \\
\text { ACCEPTED }\end{array}$ & 745 & 77 & 0 & $83.4 \%$ & 0 & 24034 & 0 & $3.8 \%$ & 5 \\
\hline Supplier 3 & 27 & $\begin{array}{l}\text { PROVISIONALLY } \\
\text { ACCEPTED }\end{array}$ & 579 & 28 & 10 & $99.0 \%$ & 12 & 11046 & 0 & $2.7 \%$ & 5 \\
\hline Supplier 4 & 0 & $\begin{array}{l}\text { PROVISIONALLY } \\
\text { ACCEPTED }\end{array}$ & 559 & 47 & 0 & $76.3 \%$ & 0 & 13289 & 0 & $6.8 \%$ & 0 \\
\hline Supplier 5 & 30 & $\begin{array}{l}\text { PROVISIONALLY } \\
\text { ACCEPTED }\end{array}$ & 428 & 36 & 5 & $72.2 \%$ & 0 & 16 & 20 & $2.5 \%$ & 5 \\
\hline Supplier 6 & 10 & $\begin{array}{l}\text { PROVISIONALLY } \\
\text { ACCEPTED }\end{array}$ & 424 & 35 & 5 & $73.4 \%$ & 0 & 8227 & 0 & $3.9 \%$ & 5 \\
\hline Supplier 7 & 5 & $\begin{array}{l}\text { PROVISIONALLY } \\
\text { ACCEPTED }\end{array}$ & 389 & 29 & 5 & $73.8 \%$ & 0 & 43791 & 0 & $10.9 \%$ & 0 \\
\hline Supplier 8 & 20 & $\begin{array}{l}\text { PROVISIONALLY } \\
\text { ACCEPTED }\end{array}$ & 382 & 21 & 10 & $87.7 \%$ & 0 & 6182 & 0 & $1.0 \%$ & 10 \\
\hline Supplier 9 & 5 & $\begin{array}{l}\text { PROVISIONALLY } \\
\text { ACCEPTED }\end{array}$ & 208 & 42 & 5 & $83.2 \%$ & 0 & 13982 & 0 & $10.7 \%$ & 0 \\
\hline Supplier 10 & 5 & $\begin{array}{l}\text { PROVISIONALLY } \\
\text { ACCEPTED }\end{array}$ & 205 & 31 & 5 & $81.5 \%$ & 0 & $104 \mathrm{~S}$ & 0 & $8.9 \%$ & 0 \\
\hline Mean & 12 & & 4720 & 39 & & $80.4 \%$ & & 12360 & & $5.70 \%$ & \\
\hline
\end{tabular}

The conducted analysis in the PCB printed circuit supplier group proved that this is by far the weakest group of suppliers in terms of the assessed indexes. The mean evaluation 
M. Gaura, M. Kuboń, Z. Kowalczyk, et.al.

score was only 12 points. Each of the assessed suppliers from this group achieved a score under 31 points, and thus all PCB suppliers received the status of Temporary Accepted. The assessment result clearly indicates that immediate corrective actions are necessary in this group of suppliers. The average delivery time was 39 days. In the case of this index for importers, the sea route was taken into account, which usually takes 6 to 8 weeks. The timeliness of deliveries is at the level of $80.4 \%$, which is caused by problems with completing orders before the date of shipment. The deliveries are partially sent in subsequent shipments or by dedicated air transport when there is an urgent demand for goods. In some cases, such a situation is dictated by the low technological advancement and efficiency of factories.

The logistic discrepancies in the admission were at $5.7 \%$. The large number of generated errors and logistical inconsistencies is partly caused by frequent reviews of deliveries for customs. Additionally, remote supplier management is very difficult. Average quality of delivery score (PPM) was 12,360. The very poor quality of deliveries also results from the technological advancement of the factories. Low price often translates into poor quality, which results in frequent returns and complaints.

In conclusion, it should be stated that in the case of the average delivery time, the shortest delivery time for the placed order was achieved for the Semiconductor supplier group, as compared to other product groups. This group is based on deliveries using highly developed distribution networks, and not directly from producers. The longest order fulfillment time is for the PCB manufacturers group, where deliveries are made only by sea. It is in the group of PCBs that the agreed delivery dates are most difficult to meet. This is due to the large distance from the supplier's premises, and thus hindered timeliness. The suppliers from the Electromechanics group are also below the lower acceptance threshold in this list. The suppliers from the Semiconductors assortment group demonstrate the best performance in terms of punctuality. A similar situation occurs in the case of logistic inconsistencies in admittance, where the most significant problems are generated by a group of PCB suppliers, where the result exceeds $5 \%$. On the other hand, the Semiconductors supplier group is definitely the leader in this respect, with the average number of incompatible deliveries at $2.7 \%$. A very large number of poor-quality products delivered by import suppliers cause considerable complications in terms of maintaining efficiency and continuity of production. This is reflected in a very high, unacceptable level of PPM. The Semiconductors group is definitely the leader in this list. However, it should be taken into account that the low PPM level is highly influenced by the huge number of delivered product lines. Therefore even in the case of noncompliance with a large number of rejected components, the PPM level is still within the acceptability threshold. In the case of this index, the largest dispersion of the measured index results was observed.

\section{Conclusions}

1. The evaluation of selected suppliers and assortment groups demonstrated that the company's supply chain is largely determined by the type of ordered goods, the place of its manufacturing and the method of its delivery to the customer.

2. The assessment of individual assortment groups has shown that the most difficult group of suppliers in terms of management and quality of deliveries and customer service is the group of PCB suppliers. Each assessed supplier was granted the Provisionally Accepted 
status. Apart from the group of PCB suppliers, the result of the assessment is acceptable for the company, especially in the full course of the year. However, there are areas for improvement for each group.

3. The highest quality of service and efficiency of the delivery process is ensured by the Semiconductor supplier group. The assessment showed that the level of supply quality for this group is not acceptable to the company. The overall level of service and the low level of quality-related non-compliance of the distributors impact a high score.

4. In order to improve the order processing process in the PCB group, it is first necessary to indicate the weakest areas of the individual suppliers' activity resulting from the conducted assessment and generating the greatest problems for the customer. Based on the above, the supplier should propose and then implement a number of activities aimed at improving its logistics process. Of course, this should be done in constant contact with the client and require his approval.

\section{References}

Blaik, P. (2010). Kluczowe wyzwania współczesnej logistyki i zarządzania łańcuchem dostaw. Struktura - trendy - doświadczenia, Gospodarka Materiałowa i Logistyka, 4, 14-19.

Bujak, A. (2015). Zarządzanie i funkcjonowanie współczesnego i perspektywicznego łańcucha dostaw. Studia Ekonomiczne. Zeszyty Naukowe. Nr 249, 50-62.

Coyle, J., Bardi, E., Langley, J. (2012). Zarzadzanie logistyczne. PWE, Warsaw. ISBN 978-83-2081864-2

Ficoń, K. (2008). Logistyka ekonomiczna. Procesy logistyczne. BEL Studio Sp. z o.o. Warsaw. ISBN: 978-83-61208-11-2.

Iakovou, E., D. Vlachos, Ch. Achillas, and F. Anastasiadis. (2014). Design of sustainable supply chains for the agrifood sector: a holistic research framework. Agric Eng Int: CIGR Journal, Special issue 2014.

Kolasińska-Morawska, K.(2011). Zarządzanie logistyczne. Wydawnictwo SWSPiZ Łódź. ISBN: 97883-62916-23-8

Krygier, J. (2011). Przedsiębiorczość i zarzadzanie. Wydawnictwo SWSPiZ Łódź. ISBN: 978-8362916-23-8

Kuboń, M. (2007). Logistyka zaopatrzenia gospodarstw rolniczych o wielokierunkowym profilu produkcji. Inżynieria Rolnicza, 6(94), 113-119.

Maloni, M.J., Brown, M.E. (2006). Corporate Social Responsibility in the Supply Chain: An Application in the Food Industry. Journal of Business Ethics. Vol.68, 35-52.

Nowicka-Skowron, M.(2000). Efektywność systemów logistycznych. PWE. Warsaw. ISBN 83-208$1332-8$

Owsiak, Z., Płócienniczak, M., Biskupski, A., Weber, R., Włodek, S. (2013). Logistics of supply of agricultural farms in the selected production means. Inzynieria Rolnicza, 3(146), 275-284.

Pfohl, H. (2001). Systemy logistyczne. Podstawy organizacji i zarządzania. Instytut Logistyki i Magazynowania. Poznań. ISBN 83-87344-10-9.

Twaróg, J. (2005). Mierniki $i$ wskaźniki logistyczne. Instytut Logistyki i Magazynowania. Poznań. ISBN 978-83-87344-91-7.

Wajszczuk, K. (2016). The role and importance of logistics in agri-food supply chains: An overview ofempirical findings. Logistics and Transport, 2(30), 47-55.

Witkowski, J. (2010). Zarządzanie łańcuchem dostaw. Koncepcje. Procedury. Doświadczenia, Polskie Wydawnictwo Ekonomiczne, Warsaw. ISBN: 978-83-208-1865-9. 
M. Gaura, M. Kuboń, Z. Kowalczyk, et.al.

\section{OCENA JAKOŚCI DOSTAW W APEKCIE OPTYMALIZACJI LAŃCUCHÓW DOSTAW}

Streszczenie. W pracy przedstawiono zagadnienie oceny dostawców jako narzędzia kontroli poziomu świadczonej obsługi przedsiębiorstwa produkcyjnego. Do pracy wykorzystane zostały dane pochodzące z wybranego przedsiębiorstwa produkcyjnego. Przeprowadzono ocenę dostawców poszczególnych grup asortymentowych oraz dokonano ich analizy. Wskazane zostały mocne i słabe obszary działalności poszczególnych grup dostawców. Stwierdzono, że łańcuch dostaw w analizowanym przedsiębiorstwie jest w dużej mierze uwarunkowany rodzajem zamawianego towaru, miejscem jego produkcji oraz sposobu jego dystrybucji do klienta.

Słowa kluczowe: logistyka, jakość, dostawa, ocena, zaopatrzenie 